\title{
Linguistic Inquiries of Unjust Sentence of Victim's Rape: A Defense from Media
}

\author{
$1^{\text {st }}$ Habiba al Umami ${ }^{1}, 2^{\text {nd }}$ Asni Furaida ${ }^{1}, 3^{\text {rd }}$ Mazroatul Ishlahiyah ${ }^{1}$ \\ \{bibamamm@gmail.com¹ ${ }^{1}$, asnifuraida33@gmail.com ${ }^{1}$, leeyamazr@gmail.com¹ \\ UIN Maulana Malik Ibrahim, Malang, Indonesia ${ }^{1}$
}

\begin{abstract}
This article discusses the media's perspective related to incest rape case in Jambi written by the editorial board and posted in The Jakarta Post's opinion column. The aim of this paper is finding out the media's evaluation toward the case using an appraisal system. The analysis is done by classifying which utterance in the data that consists of several arguments and opinions. Later on, the researchers highlight and discuss expressions which represent the media's evaluation of the government, the family member of the victim, and the whole society and state relating to the case. The result of the analysis presents that the media put their negative evaluation toward the hearing decision and sentence addressed to the victim, especially negative evaluation of judgment and appreciation. Those negative evaluations are deemed as a form of defense from media instead of a neutral commentary.
\end{abstract}

Keywords: appraisal; discourse analysis; incest rape; online media

\section{Introduction}

As in nature, media functions more than just as a medium of information. Aside from having the power to change people's attitude, belief, and habit [1], it also becomes a means for the society to deliver their opinions and ideas related to the current phenomena or issues. To serve people's aspiration, the media provides the opinion column, which becomes the media for everyone to speak on their behalf regarding the current issues. Interestingly, it is not only the society who can deliver their thought in this column but also the media itself. The editorial board of the media often writes their concern toward the current case in the opinion column. This implies that the media does not merely stand as the stakeholder of informing the social issues, but also as a part of society which gives their concern regarding the issues.

Through the existence of opinion columns, the media and journalist do not only express their perspective but put their judgment toward the case. An opinion is formed by several arguments that always belong to either pro or cons side of the story. Argumentation is an activity of justifying or refuting particular controversial phenomenon aimed to influence other people by firming up or weakening people's acceptability regarding the case by giving a rational judge [2]. Therefore, the arguments written by the editorial board of the media in the opinion column reflects the media's judgment regarding the particular controversial social issues. Thus, when media puts their opinion, judgment, and even argumentation in the opinion column, they also try to control public opinion and perspective regarding the case. Through media, the variety of ideas influence other people [3]. Up to this point, media is no longer the neutral party which merely aims to keep the society informed by current status quo. 
Following the concept above, this paper aims to reveal The Jakarta Post's standpoint regarding rape case in Jambi. The data of this paper are the opinion column's post written by the editorial board entitled Treat Rape Victim as Victim. This case is interesting to analyze because the rape victim, in this case, is sentenced to jail because she committed an abortion. Furthermore, up to this post is released, the girl was not deemed as a victim because the prosecutors and judges regarded the incest sexual intercourse as a consensual intercourse. To get the result, the writers focus to analyze the media's judgment embedded in their opinion and argumentation written in the post.

To discover the text producer's judgment in the text, the writer employs appraisal theory in analyzing the data. Appraisal covers the resource of appraisal used by people in negotiating their social relationship [4]. The social relationship is inferred through the text producer's attitude by pointing out which affect (feeling), judgment, and value are expressed [4]. Further, the text producer's attitude becomes the justifying resources to influence the reader of The Jakarta Post to portray the case as same as the editorial board of The Jakarta Post. Eventually, it becomes the text producer's strategy to lure the reader to believe in him.

To get a comprehensive and detailed analysis, the researchers employ the descriptive qualitative method. By using the qualitative approach, the researcher focuses on meaning embedded in people's experience by unfolding how people make sense of their lives and experiences, as well as how they interpret them [5]. Firstly, the researchers classify which utterance contains an opinion and argument. Secondly, the utterances containing several arguments and opinions become the excerpt of the paper. Thirdly, the researchers highlight expression which represents the media's evaluation of the case. Lastly, those expressions are discussed based on the appraisal system.

\section{Literature Review}

Scholars have agreed that communication becomes a pivotal basis for changes in thinking [6]. Therefore, online media, as any other communication tools, serves not only for sharing and distributing information but also provoking its reader through its text. Text becomes the resources of analyzing discourse because it consists of the people's cognition toward the world and the social interaction within them [7]. It is also seen as a medium for the text producer to spread out his ideology to the reader or listener and provoking them to believe as what the text producer does [8]. Ideology is a system of belief and values upheld by the text producer based on his perspective in interpreting and representing the world [8]. However, ideology should not be explicitly asserted in the text, it interplays within the choice of word and structure of language used by the text producer [8].

One of the theories that deems language in the text is a resource of meaning-making and resource of any beliefs or ideology asserted by the text producer are Systemic Functional Grammar. It views language as a resource for making meaning [9]. Through SFG, language is deemed systemic and functional. It is systemic because word choice is formed through a system and it is functional because language is socially functioned for particular communicative goals [10]. In SFG, there are three meanings related to the context of the situation; ideational, interpersonal, and textual. Ideational meaning reflects in what is being talked about [11]. Interpersonal metafunction signifies the social relationship negotiated in the text and people's evaluation of the current affairs [4]. Textual meaning allows us to understand the text holistically through the coherence and cohesion systems. 
Appraisal theory is the fundamental element in interpersonal systems [12]. It signifies the social relationship negotiated in the text and people's evaluation of the current affairs [4]. In appraisal, there are three aspects which can be the resources of appraisal; attitude, how it is amplified and the source of it. Attitudes refer to the scheme of meaning-making which stress the framework of mapping feelings [13]. In negotiating attitudes and evaluating the social relationship, there are three alternative options; affect, judgment, or appreciation [4]. Affect represents the speaker's feeling drawn in the text, judgment reflects the speaker's evaluation regarding of someone's character, and appreciation refers to the evaluation of value asserted in the text [4].

Several studies have been conducted in the scope of appraisal theory. For example, English song is analyzed using an appraisal system to discover the emotions of the songwriter [12]. From the paper, the emotions in the song build the relationship between the songwriter and the reader [12]. The article used the appraisal system to analyze the visual beauty drawn in verbal message advertisements [14]. Her paper revealed that appraisal tools dominate moral judgment with the positive character as a praise and negative one as a criticism. The article entitled Appraisal Analysis: Thailand in the View of Phnom Penh Post on the Preah Vihear Issue reveals how Thailand and Cambodia are viewed through the English newspaper of Cambodia. The result showed that Thailand is negatively evaluated and Cambodia is positively evaluated [15].

Several scholars also used the appraisal system in conducting sentiment analysis drawn in a text. They discussed whether the appraisal system could be an effective means for sentiment analysis $[16,17,18]$. They found out that appraisal taxonomies or frameworks have helped them classifying the positive and negative sentiments in the text $[16,17,18]$. Furthermore, a political news article reporting on Iraq and its economic policies is analyzed using the appraisal system to find out various aspect of sentiment drawn in the text [19]. The result indicates that the appraisal framework has been useful to uncover the sentiment featured in the text [19]. Not to mention, sentiment analysis based on appraisal theory is also utilized in analyzing the marketing intelligence in Indonesia's mobile phone market [20]. The result reveals the positive and negative sentiment toward several mobile phone products in Indonesia [20].

In this paper, the researchers do not only reveal how appraisal system is used in analyzing the positive or negative evaluation of the speaker toward the case but also discuss the standpoint of the media as the text producer in evaluating the social phenomenon. Therefore, the linguistic scope in analyzing the media's evaluation regarding the rape case in Jambi is extended into the social analysis.

\section{Methods}

This paper examined The Jakarta Post's standpoint regarding rape case in Jambi on July, $24^{\text {th }} 2018$. The data is the opinion column's post written by the editorial board entitled Treat Rape Victim as Victim available online. However, the posting taken as the data are those containing the media's judgment embedded in their opinion and argumentation written in the post. Moreover, this study was only focused to analyze the data using appraisal theory since it discovered the text producer's judgment in the text.

Furthermore, the researchers apply descriptive qualitative method which focuses on meaning embedded in people's experience by unfolding how people make sense of their lives 
and experiences, as well as how they interpret them [5]. Firstly, the researchers classify which utterance contains an opinion and argument. Secondly, the utterances containing several arguments and opinions become the excerpt of the paper. Thirdly, the researchers highlight the expression which represents the media's evaluation of the case. Lastly, those expressions are discussed based on the appraisal system.

\section{Findings and Discussion}

This section consists of two parts. The first part is the findings which describe the types of attitude found in the text. The second part is the discussion which elaborates the strategy of luring the audiences drawn in particular attitudes found in the text.

\subsection{Findings}

To ease the discussion, this section is classified based on the stakeholder of the rape case and trial which is being criticized by the text producer. There are at least three stakeholders that are being judged; the government, the family member of the victim (especially the mother and the brother), and the whole society and state, including the media, police, prosecutors, judges, the village apparatus, and customary leaders. Therefore, the findings are grouped based on these three stakeholders.

\subsection{The Government}

Judging the criminal wrong is common, but judging the government which fails to analyze the guilty one is another matter. In this case, the text producer put his judgment to the government because they do not merely accuse the brother of the girl as the rapist but also labels her as criminal. The elaboration of the text producer's judgment to the government is explained below:

Excerpt 1: Human rights activists have called on the government to review the case and release the girl because she is a minor and by her own brother's admission, a rape victim (negative judgment: condemnation).

The implication of the negative judgment in the excerpt above is inferred through the expression "have called the government to review and release the girl". There are two actions asked by the human rights activist to the government; review the case and release the girl. Each act has implied different condition regarding to the case. First, the text producer uses the word review, which implies that it is not enough for the government to view the case once and accuse the girl guilty. In other words, The Jakarta Post believes that the government's view, in this case, needs to be evaluated. Second, the media also state that the reason why the girl victim needs to be released. This infers that in the current status quo, the girl has not been released from jail by the government based on the decision hearing. Indeed, these two judgments are not those two inferences belong to the act of condemning the government.

Excerpt 2: The Legal Aid Foundation of the Indonesian Women's Association for Justice (LBH APIK) said sexual and reproductive health services for rape victims in Indonesia, including access to emergency contraception that could prevent an unwanted pregnancy after the rape, were not always available in every region (negative judgment: condemnation).

Another act of condemning the government is drawn in excerpt 2. The use of the adverb "always" in the excerpt above implies the fact that sexual and reproductive health service in Indonesia should be available at all times. Yet, this condition has been refuted by the use of 
negation "not" before the adverb. This indicates that in nature, it is the government responsibility to provide and give the sexual and health services to the rape victims but they have failed to do so. This situation describes that the government has not concerned with the needs of the rape victim, which eventually makes the text producer feels sorry for the victim.

Excerpt 3: However, emergency contraception should be part of "a full range of services", said Wulan Danoekoesomo, the founder of the rape survivor support group Lentera Indonesia. Victims needed sexually transmitted disease prevention and physical and psychological help, she added. (negative judgment: condemnation)

The expression of "should be" in excerpt 3 indicates the ideal pack of sexual and health service provided by the government for the rape victims. This auxiliary functions to describe the obligation and the ideal condition that should be met by the stakeholder. In this case, the use of this auxiliary implies that in the status quo the needs of health and sexual services have not been met, especially for the victim itself. As in excerpt 2, this also implies that the government has missed one of its responsibilities, giving the victim's needs as a victim.

Excerpt 4: Certainly, a jail sentence is the last thing a rape victim needs (negative judgment: condemnation).

$\mathrm{Up}$ to this news is released, the girl victim is sentenced to jail because of the abortion accusation. Because of this decision hearing, the text producer judges the government negatively. Using the adjective "last", the text producer criticizes the government's decision because they should not put the girl victim in jail easily. It also implies that there are a lot of other options that could be considered by the government before deciding to sentence the girl in jail. However, in fact, the government does not seem considering the other options. This judgment has been made by the text producer in a strong force through the expression of "certainly". This force indicates that the text producer makes a strong affirmation toward his condemnation.

\subsection{The family member of the victim}

Since it is an incest rape, another stakeholder in the case that is being criticized by the text producer is the family member of the girl victim. More specifically, the ones who have been judged by the text producer is the mother and the rapist itself, her brother.

Excerpt 5: Second, the girl's mother, 38, admitted she was the one who massaged the baby out of the womb, with her own hands. (negative judgment: condemnation and negative appreciation)

The excerpt above belongs to both negative judgments (condemnation) and negative appreciation addressed to the girl's mother. These negative judgments and appreciation are addressed due to the abortion which is done by the girl victim with the major help coming from her mother. The condemnation and the negative appreciation are drawn through the expression "with her own hands". It is already common to know that massage is done using the hand of the masseur. Therefore, saying that the abortion is done with the help from the hands of the girl's mother is actually not aimed as an information but as a portrayal of the irony. Everyone knows that the nature of a mother is protecting and loving woman to her children. Yet, in this case, the mother, who is supposed to protect, makes the girl suffer more due to the abortion. Thus, the text producer condemns the mother's attitude which is not protecting her daughter and depreciates her actions.

Excerpt 6: What could a 15-year-old girl, who had been sexually assaulted at least seven times by someone who should have protected her and had borne the consequences all alone for months (negative judgment: condemnation and negative appreciation), say to her mother? 
Another family member who is being condemned by the text producer is the brother, rapist itself. The condemnation toward the family of the girl victim in the excerpt above is drawn through the failure of the girl's brother, as the rapist, to protect and borne the consequences for the thing he has done. As mention above, the expression "should" indicates that the ideal condition has not been met by the stakeholders. In this case, the protection which should come from the brother has not been met by the girl victim. Not to mention, the rapist, the brother, also fails to be responsible for the rape and leaves the girl alone to face the consequence in saying about her condition towards her mother. Not to mention, to get the reader's sympathy, the writer tries to provoke the reader's feeling by inviting them to place themselves as the victim through the use of rhetorical questions.

\subsection{The whole society and state}

Another stakeholder which is portrayed by the text producer is the whole society and state, including all the social member involved in this case and decision hearing.

Excerpt 7: First, it was not incest, it was rape (negative appreciation).

In this excerpt, the text producer clarifies how the case looks like for him. The text producer uses the term with a stronger force to describe the case. He refuses to deem the case as an incest. He states that the case is worse than just an incest, it is rape. Incest indicates that the sexual intercourse done by the family member is a form of sexual relation which may be consensual. By saying that it was rape, not an incest, the text producer seems to eliminate the possibility that the sexual relation may be consensual. In the case of rape, there is no possibility that the sexual intercourse is done by respecting the victim's consent. This possibility is the main point that the text producer wants to highlight.

Excerpt 8: It is baffling to find that the media, the police, prosecutors, judges, the village apparatus and customary leaders all have failed to see her for what she really is: a victim. (negative appreciation)

"Fail" refers to the condition which the stakeholder cannot achieve several purposes or goals. Unlike the negative judgment, the negative appreciation is addressed to criticize things. In this case, the text producer criticizes the work of all media, police, prosecutors, judges, the village apparatus and customary leaders, which has not been successful to analyze the case and give the fair judgment toward the girl victim. As the victim, the girl should be defended and protected by giving her the fairest decision. However, the fairest condition has not been achieved and it makes the text producer depreciate the work all the stakeholders involved in the decision hearing.

Excerpt 9: The Jambi case is not the only one where the state and society treat a rape victim not as a victim, but as a perpetrator (negative appreciation).

The failure of the state and the society in giving the fairest decision and the best defendant toward the rape victim is elucidated in excerpt 9 . To make it clear, the text producer even points out the label put by the state and society towards the girl victim, a perpetrator. He also strengthens his statement by giving a negation towards the label of "victim". Thus, the failure of treating the rape victim as a victim is criticized by the text producer.

Excerpt 10: And for the record, most incest cases in Indonesia are actually sexual assaults, not consensual relationships (negative appreciation).

Another phenomenon which is highlighted by the text producer is the nature of incest cases. While several people deem incest cases are a consensual relationship, the text producer negates this point by saying that it is actually an assault. This critic belongs to the negative appreciation because the text producer wants to highlight that there is a loss of respectability 
point in the case of incest rape. Not to mention, the use of the adverb "actually" indicates the strong force made by the media as the text producer in claiming his opinion.

Excerpt 11: Father and daughter, older brother and sister, uncle and niece, mother and son: the hierarchy in the relationship says it all (negative appreciation).

To enhance the media's reasons in pointing out that incest rape is an assault, the media also criticize the hierarchy of the family. By mentioning the relationship of father and daughter, older brother and sister, uncle and niece, mother and son, the media implies that the lower hierarchy of the family is the victim of the assault while the higher hierarchy in the family becomes the rapist. Therefore, it has the lowest possibility when the incest intercourse is done with consent from two parties. The expression "says it all" indicates that it is clear enough for the text producer to argue that incest sexual intercourse is a rape.

\section{Discussion}

From the analysis above, the media as the text producer points out three stakeholders; the government, the family member of the girl victim, and the whole society and state. In evaluating the government, the media judge the government as an active stakeholder in resolving and giving the decision towards the girl. The media negatively judge the government because he deems that the decision hearing for the girl victim is unfair. He also points out several major points that cannot be given by the government as the one who serves the society and protects the criminal's victim. After judging the government, the media has also judged the girl's brother and mother. In judging those two family members, the media put his negative judgment and his negative appreciation. The negative judgment is addressed due to their negative behavior towards the girl victim. Meanwhile, the negative appreciation is delivered because of their irresponsibility in protecting the girl. The last stakeholder that is being pointed out is the whole society and state. Unlike the first stakeholder, government, which is being judged because of their behavior and decision, the critics towards the whole society and state represent the media's perspective in evaluating the way society and state treat and regard the girl victim. Thus, it is more evaluating the perspective of the society rather than the society itself. Therefore, all 5 excerpts related to this stakeholder belong to the negative appreciation.

Notice that all of the evaluations appraised by The Jakarta Post are the negative evaluations. The negative judgments and negative appreciations addressed to the stakeholders who are deemed unjust reflect the standpoint of the media itself. Instead of being in the same boat with the government, the family member of the victim, and the whole society and state, The Jakarta Post put his position in supporting the defending the victim through its critics. The media's evaluation by showing up the infamy of the stakeholders discussed above provoke the readers to also put their negative judgments toward the three stakeholders above and give their empathy to the victim.

\section{Conclusion}

11 excerpts have been analyzed and 13 appraisal resources have been found. In judging the government, the media put his negative judgment or condemnation towards their behavior in considering the rape case in the fairest state. Another negative judgment related to the improper behavior is also addressed to the victim's mother and brother. The judgment towards 
the girl's mother and brother also belongs to the negative appreciation because it also implies the irresponsibility from those two family members in protecting the girl as of how she should be. Not to mention, the perspective of the whole society and state in seeing the incest rape is also being negatively evaluated by the media, through the expression of depreciation (negative appreciation). All of these negative evaluations are considered as a defense from media for the victim rape.

Acknowledgements. This paper in conjuction with The 1st Annual International Conference on Language, Literature and Media (AICoLLiM 2018) in Malang, East Java.

\section{References}

[1] B. Mehraj, \& Mehraj. 2014. Impacts of Media on Society; A Sociological Perspective. International Journal of Humanities and Social Science Invention, 2014 .http://www.ijhssi.org/papers/v3 (6)/Version-4/L0364056064.pdf,2014.

[2] F. H. van Eemeren, R. Grootendorst, F. S. Henkenmans, J. A. Blair, R. H. Johnson, E. C. Krabb, C. Plantin, D. N. Walton, C. A. Willard, J. Woods, \& D. Zarefsky. Fundamentals of Argumentation theory: A handbook of historical background and contemporary developments. Hillsdale, NJ: Lawrence Erlbaum Associates, Inc. 1996.

[3] J. Bryce. The nature of public opinion; Extract from The American Commonwealth, Holmes Beach, Fla: Gaunt Inc. 2010.

[4] Martin and Rose. Working with Discourse: Meaning Beyond the Clause. London: CPI Bath. 2003.

[5] Merriam. Case Study Research in Education, A Qualitative Approach. London: Jossey Bass Publishers. 1988.

[6] Schwarz \& Asterhan. Argumentation and Reasoning. Elsevier Handbook of Educational Psychology: New Perspectives on Learning and Teaching. Elsevier Press. 2008.

[7] Fairclough, Norman. Critical Discourse Analysis: The Critical Study of Language (First Edition). New Yorks: Longman Publishing. 1995.

[8] Fairclough, Norman. Language and Power. Jurong: Longman Singapore Publisher (Pte). Ltd. 1989.

[9] Gerott and Wignell. Making Sense of Functional Grammar. Australia. Gerd Stabler. 1995.

[10] Bache. "Hjelmslev's Glossematics: A source of inspiration to Systemic Functional Linguistics". Journal of Pragmatics: An Interdisciplinary Journal of Language Studies, vol. 42 no. 9, 2010. p. 2562-2578. Elsevier Ltd, www.elsevier.com/locate/pragma, 2014.

[11] Butt et.al. Using Functional Grammar; An Explorer's Guide. Sydney: Macquarie University. 2001 .

[12] X. Li. An Attitudinal Analysis of English Song Discourse from the Perspective of Appraisal Theory. Journal of Language Teaching and Research, vol. 7 no. 3, 2016. p. 559-565. http://dx.doi.org/ 10.17507 /jltr.0703.17.

[13] Martin and White. The Language of Evaluation: Appraisal in English. New York: Palgrave Macmillan. 2005.

[14] Tiani. Judgement Sebagai Sistem Appraisal dalam Iklan Kecantikan Visual Media Cetak. NUSA, vol. 12 no. 4, 2017. https://ejournal. undip.ac.id/index.php/nusa/article/view/16868/12246.

[15] Songsukrujiroad, chaiyasuk, praphan. Appraisal Analysis: Thailand in the View of Phnom Penh Post on the Preah Vihear Issue. Thammasat Review, vol. 18 no.2, 2015. P. 96-115. https://tcithaijo.org/ index.php/ tureview/article/view/67875/55356.

[16] Fletcher and Patrick. Evaluating the utility of appraisal hierarchies as a method for sentiment classification. In: Proceedings of the Australasian Language Technology Workshop 2005. 2005. p. 134-142. 
[17] Whitelaw, Garg, Argamon. Using appraisal groups for sentiment analysis. In: Proceedings of the 14th ACM international conference on Information and knowledge management. ACM, 2005. 2005. p. 625-631.

[18] Bloom, Kenneth. Sentiment analysis based on appraisal theory and functional local grammars. Illinois Institute of Technology, 2011.

[19] Khoo et.al. Sentiment Analysis of Online News Text: A Case Study of Appraisal Theory. Online Information Review 36:6. 2012. 858-878

[20] Alamsyah, Rahmah, and Irawan. Sentiment Analysis Based on Appraisal Theory for Marketing Intelligence in Indonesia's Mobile Phone Market. Journal of Theoretical and Applied Information Technology 82.2. 2015 